\title{
CHILDHOOD INTERVENTION AGAINST VIOLENCE
}

\author{
Goetz Egloff $^{1^{*}, \text { Dragana Djordjevic }}{ }^{2}$ \\ ${ }^{1}$ Practice for Psychoanalysis and Psychotherapy, Mannheim, Germany \\ ${ }^{2}$ University Children's Clinic, University Clinical Center, Niš, Serbia
}

\begin{abstract}
Violence has its roots in many factors. Structured interventions for children can be useful when it comes to building emotional competencies. Self-regulation of negative emotions, impulse control, and empathy are important competencies to be achieved in order to prevent violence. The 'Faustlos' ('No Fists') program, which was designed to learn how to deal with emotions as well as to develop empathic dealings with one another, offers a wide variety of techniques and strategies for children. Furthermore, children are given a secure realm of learning and transfer in which no-one is excluded and stigmatization is avoided. With the additional involvement of parents, new modes of intra- and interpersonal conflict solutions in families can be developed. Its special relational approach makes the program convincing as a tool for childhood intervention. The development of pro-social emotions should be a base for the prevention of bullying and violence. Implementation in Serbia might be useful.
\end{abstract}

Key words: childhood, intervention, empathy, impulse control, coping.

\section{Introduction}

Children with aggressive and violent behavior inflict injuries on others, either physically, psychically, or both. As to a multi-factorial concept of the generating of aggressive and violent behavior, it is mostly important to intervene early in the socialization process of children. Not only does the personal organization of emotions take place in childhood [1] but interactional processes of recognition, of boundaries and of intersubjective experiencing allow the creation of subjectivity. Therefore, especially the family and institutional surroundings of childhood play a significant role in supporting personal individuation, which allows for a communicative mode of non-violent dealings. Expansion and initiative in children are not to be eliminated but aggressive impulses of destructive color directed toward pro-social application instead. Destructive aggression has to undergo a subtle transformation into behavioral modes that are socially acceptable.

\section{Violence}

Although the expression of violence in everyday life is easily imaginable, it should be said first that quite different phenomena have to be subsumed under the term violence. In his influential writings, Žižek [2] reasonably differentiates subjective from objective violence. Subjective violence, which is the common

*Correspondence to: Mag. Goetz Egloff

Richard Wagner St. 18, 68165 Mannheim, Germany

E-mail: g.egloff.medpsych.ma@email.de

Received September $25^{\text {th }}, 2017$ notion of violence, is performed by a clearly identifiable agent. Then there is objective violence in two forms: symbolic violence is embodied in language and its forms, and systemic violence is the phenomenon of consequences of the smooth functioning of economic and political systems [3]. Subjective violence is experienced as such against the background of a nonviolent zero-level. Objective violence is invisible since it sustains the very zero-level standard against which we perceive something as subjectively violent. Irrational explosions of subjective violence can better be understood via its counterpart, which is the objective one [4]. Systemic violence as inherent in western capitalism affects the formation of subjectivity, i.e. psychic development of people. It is not visible, yet it has effect on people via the more subtle forms of coercion that sustain relations of domination and exploitation [5]. Additionally, in a worldwide view, limitation of tolerance is the predominant notion underpinning today's ideology $[6,7]$. It might be that a broad range of personal freedom, such as in today's liberal societies, will entail its opposite, which is restriction. From this perspective the question arises whether liberalism itself leads to an incline of fundamentalism automatically [8], encompassing violence in all its different forms.

In the following we are dealing with subjective violence, which is commonly referred to as aggressive and violent behavior in people. As social scientists like Hurrelmann [9] and Heitmeyer [10] have broadly shown, such behavior is a "social disease", generated by intrapsychic, interpersonal and societal conflicts. Children may express threats, or destroy objects. Such actions appear in contexts such as family, kindergarten, 
and school. Yet, the location of conflicts is often not identical with the location of expressed aggression or violence. Conflicts at home may be enacted in school or kindergarten, and experiences of victimization and conflict from school and kindergarten may be brought back home, leading to aggressive behavior, e.g. in siblings or in family interaction. At any rate, aggressive behavior is mostly used as a personal "solution" of interpersonal conflicts. Escalating situations that seem to leave no other option of communication often lead to violent acting [11].

There is a consensus that the expression of emotions in the course of human development is learned to some extent, as has internationally been discussed in conferences such as those on social-emotional learning [12]. This holds true for aggressive and violent behavior. Aggressive and violent children often have a dysfunctional family background [13] in which parents are not capable of taking enough care of their children, either physically or psychically. Sometimes there is a lack of attachment in the mother-infant-relation existing from birth on, or there are disorders of early attachment that have developed in children's first year of age [14]. Different sorts of dysfunctional modes in parents' behavior can affect the infant's emotional development since parent-infant interactional processes are prone to dysfunction. Intuitive parental competencies fundamentally influence the infant's emotional development and are vulnerable [15]. The loss of societal structure may disturb families in developing consistent educational modes [16]. Even social status and the overall status of societal development may compromise these competencies $[17,18]$. Dysfunctional and non-coherent educational practices in some families can puzzle and disturb children and direct their development toward dysfunctional modes of behavior. Moreover, aggressive children have often been victims of violence themselves [19]. Additionally, TV programs, video games and other media of violent contents mediate violence as a means of conflict solution. Children consuming many of these programs tend to use violence in dealings with their peers more often than those who do not [20]. As one can see, in order to prevent violence many subjects have to be dealt with.

To sum it up, children have partially learned to react in violent ways. Aside from an intrapsychic processing perspective, there is a social learning perspective that is still useful for the development of new modes of dealing with one another. It can be seen that in the last hundred years there have been great improvements in dealings with children [21-23], and when we look at publications on childhood development [24], it can be stated that scientific knowledge has hugely grown. Developing of subjectivity remains a multi-factorial process $[25,26]$ which today is even more threatened by commodification, as health services are by economization of policies [27].

\section{What Children Don’t Know About}

Early childhood is the most sensitive period of behavioral learning. Pro-social behavior can be learned to some extent. It is often impaired both in clinically conspicuous and in "normal" children. Modes of pro-social dealings with one another are by no means common in many families, nor do such come out of the blue. This is why, quite often, children [28]:

- don't know about appropriate behavior in certain situations since they don't have an inner working model of alternative conflict solution

- they do know about appropriate behavior but haven't been supported enough in doing so

- they show emotional reactions like anger, fear or anxiety that keep them from developing appropriate behavior

- they are not able to assess aggressive behavior appropriately

- they may have physiologically-based developmental deviation or disabilities stemming from genetic or parental influence.

\section{Faustlos and Second Step}

Faustlos (meaning 'No Fists') is an adaptation of Second Step [29], designed as an emotional learning program to shape skills and competencies through an interactional framework. At the heart of Faustlos there are three issues to be transferred to children: (1) getting to know empathy and the training to be empathic, (2) learning to be capable of controlling one's impulses, and (3) dealing with emotions of anger and rage. These issues are playfully dealt with in the kindergarten curriculum by way of 28 continuous lessons. Each lesson contains a story that is told by the educator and is illustrated by an accompanying picture. Each lesson is structured the same way: at first, the topic of the lesson is outlined by playfully fantasying what the lesson will bring. Moreover, in theater atmosphere, hand puppets (a toy dog and a toy snail) open up getting in contact with each other, further illustrating the issue of the lesson to come. This is followed by the actual lesson in which the story is told, shown in the picture, and discussed with the group. Role-playing, or alternative exercises at the end of the lesson will make sure the transfer to everyday life of children is initiated. The children are encouraged to try new approaches in kindergarten and at home too, therefore the parents are separately educated, too. Additionally, the educator is advised to return to the contents of the lesson during the following week. The program is conducted by a constant relational person, i.e. childcare worker as educator, in a closed group cycle of one year. Ideally, one lesson per week is conducted. 


\section{Lessons of the Kindergarten Curriculum}

The lessons follow a consecutive order that will become more complex the further the topics develop. At first, fundamental emotions are dealt with, and the focus is on empathy. After that, coping strategies for dealing with negative emotions in interaction are focused at.

I Empathy:

1. What is Faustlos?

2. Emotions (joy, grief, anger)

3. Emotions (surprise, fear, disgust)

4. Same or Other

5. Emotions Change

6. If... Then...

7. Not Now - Maybe Later

8. Mishaps

9. What is Just?

10. I am Feeling...

11. Active Listening

12. I Care

II Impulse Control:

1. Calming Down

2. What is the Problem?

3. What can I do?

4. Choosing

5. Will it Work?

6. Sharing

7. Taking Turns

8. Negotiating

9. Listening

10. Interrupting Politely

III Dealing with Anger and Rage:

1. Am I Angry?

2. Calming Yourself Down

3. Dealing with Violations

4. Dealing with Name-Callings

5. Dealing with Getting Something Taken Away

6. Dealing with Not Getting What You Want

Parental involvement is part of the curriculum, too. By way of continuous parental meetings, parents grow accustomed to dealing with their children, and with one another, in rather empathic and non-violent terms. Ideally, new modes of intra- and interpersonal conflict solutions are developed with the parents. Specific accompanying courses and additional literature are offered to the parents, too [30].

Self-regulation, especially, has been proven to be difficult in traumatized and insecurely attached children, even sometimes in anxious children [31]. Faustlos offers a wide variety of techniques and strategies for children to learn how to cope with inner impulses by broadening the range of possible reactions in stressful and conflict situations. A special accent is given to change of perspective through stories viewed from different personal viewpoints in teaching lessons; something which has regularly been experienced revelatory in groups and audiences. Perspective changing and roletaking is highly important for psychic development: it was Sigmund Freud who observed early in his carrier that parts of what one observes can be fiction, i.e. something may not be what it seems to be [32].

Also from a differently conceptualized perspective of hysteria and borderline dynamics [33], children will respond to a well-structured offer of interactional experiencing, even when it cannot supply solutions to each and every shortcoming of personal and social issues. An anthropological constant of psychic pathology might have to be conceded [34], as well as the fact that there are culturally biased views of pathology, e.g. in psychic trauma theory [35]. Ratings highly depend on subjective construction [36].

\section{Evaluation and Implementation}

International evaluations of both Faustlos and Second Step proved these anti-violence programs to be effective [37]. Faustlos has been implemented at many educational institutions in Germany since 2001, such as in kindergarten and elementary schools, later on also in secondary schools.

The German Faustlos kindergarten curriculum was developed and evaluated between 2001 and 2004 at the University of Heidelberg. A process evaluation [38] was followed by a pre/post randomized control trial (RCT) study which compared the behavior of children in kindergartens which did and kindergartens which did not conduct the program. The study proved the program to be effective especially as to a decrease of verbal aggression in children $[39,40]$. Identifying emotions turned out to be easier for children who took part in the program than for those who did not; the same was shown for pro-social dealings with conflicts. Generally, Faustlos has been proven to have a specific anxietyreducing effect supporting the transfer of competencies to everyday life [41] which is highly important since effects on the level of personal emotion entail even more appropriate interpersonal, pro-social behavior [30]. Further development and evaluation of the program in secondary education institutions followed from 2005 to 2007 , so that evaluation of the program was conducted both in elementary and in secondary education [42-45]. Having been well-implemented at many educational institutions in Germany [46], the 'No Fists' program has even found its way into educational science text books [47]. The overall response of acceptance which is also due to the special relational approach tells of the program to be convincing.

Concerning violence prevention in Serbia, there is a program titled 'School without Violence - Towards a Safe and Enabling Environment for Children' whose implementation started in 2005 through UNICEF, the Ministry of Education and Science, the Ministry of Labor and Social Policy, the Ministry of Health, the Council for Child Rights, and the Office for Educational Development and Improvement [48]. The project involves everyone at school in a process of training and education during which they learn how to recognize, prevent and properly react to any instances of violent behavior. An 
educational component of this program contains education for teaching staff about skills of constructive communication, open dialogue between children and adults in schools, and conflict management $[49,50]$. The term violence in this project does not only imply physical violence but all other forms of insults and verbal harassment. Six years later, in 2011, it was reported that sensitivity to violence increased significantly, popularity of violent pupils dropped, while both children and adults in schools that took part in the project increased their capacity to recognize violence and respond to it better, whereas cooperation with the local community and with parents was rated the least successful component of the program. Only about $20 \%$ of elementary schools have been involved [48].

Although there have been great efforts, violence is present worldwide. In order to prevent violence, it is highly important:

(1) to take prevention steps before violent behavior actually happens;

\section{References}

1. Grossmann KE. Die Bedeutung der ersten Lebensjahre für die Organisation der Gefühle [The pertinence of first childhood years for the organization of emotions]. In: Dörr M, Göppel R (eds). Bildung der Gefühle. Innovation? Illusion? Intrusion? [Education of Emotions]. Giessen, Psychosozial 2003; 123-145.

2. Žižek S. Violence: Six Sideways Reflections. London, Profile 2008 .

3. Žižek S. Violence: Six Sideways Reflections. London, Profile 2008; 1 .

4. Žižek S. Violence: Six Sideways Reflections. London, Profile $2008 ; 2$

5. Žižek S. Violence: Six Sideways Reflections. London, Profile 2008; 8 .

6. Žižek S. Violence: Six Sideways Reflections. London, Profile 2008; 174.

7. Egloff G. Ten Theses on the Spirit of Terrorism. Int J Terrorism and Political Hot Spots 2016; 11(1):13-27.

8. Žižek S. Blasphemische Gedanken [Blasphemic Thoughts]. Berlin, Ullstein 2015; 15

9. Hurrelmann K. Aggression und Gewalt in der Schule - Ursachen, Erscheinungsformen und Gegenmassnahmen [Aggression and violence at school - origins, phenomena, interventions]. Pädagogisches Forum 1992; 5(2):65-74.

10. Heitmeyer W. Gewalt [Violence]. Weinheim, Juventa 1994

11. Ratzke K, Sanders M, Diepold B, Krannich S, Cierpka M. Über Aggression und Gewalt bei Kindern in unterschiedlichen Kontexten [On aggression and violence in children in different contexts]. Prax Kinderpsychol Kinderpsychiatr 1997; 46(3):153-168.

12. Cierpka M, Schick A, Ott I, Egloff G. 2nd International Conference on Social-Emotional Learning. Heidelberg, University of Heidelberg, Oct. 8-9, 2001.

13. Cierpka M. Kinder mit aggressivem Verhalten. Ein Praxismanual für Schulen, Kindergärten und Beratungsstellen [Aggressive behavior in children]. Göttingen, Hogrefe 1999

14. Grossmann KE, Fremmer-Bombik E, Friedl A, Grossmann K, Spangler G, Suess G. Die Ontogenese emotionaler Integrität und Kohärenz [The ontogenesis of emotional integrity and coherence]. In: Roth E (ed). Denken und Fühlen. Aspekte kognitiv-emotionaler Wechselwirkung [Thinking and Feeling: Aspects of CognitiveEmotional Interaction]. Berlin, Springer 1999; 36-55.

15. Papoušek M, Cierpka M. Der klinische Blick: Grundlagen und Gefährdungen der intuitiven elterlichen Kompetenzen [The clinical view: basics and endangerings of intuitive parental competencies]. Presentation, 62. Lindauer Psychotherapiewochen Congress, April 19, 2012.
(2) to build an emotional foundation for non-violent dealings with one another in each child, the earlier in life the better;

(3) to make pro-social behavior second nature. The scientific findings show that this is possible via early interventions;

(4) to involve parents and make them familiar with principles of non-violent and respectful dealings with one another. Parental involvement is an important component of the Faustlos program;

(5) to approach all children, not excluding any child, not differentiating them into violent and nonviolent and, especially important, not stigmatizing them after having been violent. This is also an advantage of Faustlos;

(6) to use well-evaluated programs. Faustlos is a scientifically evaluated program.

Therefore, Faustlos might be appropriate for implementation in Serbia, too.

16. Egloff G. Die Irrationalität durchdringen. Zwischen der Operationalisierung psychodynamischer Diagnostik, Lacan und Jaspers - zum psychodynamischen Verstehen in der Postmoderne [Permeating irrationality: on the operationalization of psychodynamic diagnostics, Lacan, and Jaspers - psychodynamic reasoning in postmodernity]. Deutsches Ärzteblatt PP 2012; 11(8):358-360.

17. Egloff G, Djordjevic D. On pre- and postnatal mental health intervention concepts. In: Williams J (ed). Psychopathology Symptoms, Challenges and Current Concepts. New York, Nova Science 2016; 133-170.

18. Egloff G, Djordjevic D. Pre- and Postnatal Psychosocial Intervention Concepts. Eur Psychiatry 2017; 41(4):S734.

19. Levold T, Wedekind E, Georgi H. Gewalt in Familien Systemdynamik und therapeutische Perspektiven [Violence in families: system dynamics and therapeutic perspectives]. Familiendynamik 1993; 3:287-311.

20. Bandura A. Aggression: A Social Learning Analysis. Englewood Cliffs, Prentice Hall 1973

21. Kaus G. Die seelische Entwicklung des Kindes [Psychic development of children]. In: Wexberg E (ed). Handbuch der Individualpsychologie [Handbook of Individual Psychology]. Vol. 1. Munich, J.F. Bergmann 1926; 137-168.

22. deMause L. Was ist Psychohistorie? [What is Psychohistory?]. Giessen, Psychosozial 2000

23. Djordjevic D, Egloff G. Frühe Kindheit: Intuitive Elternkompetenzen fördern [Early childhood: supporting intuitive parental competencies]. Deutsches Ärzteblatt PP 2016; 14(2):68-69.

24. Cierpka M (ed). Frühe Kindheit: 0-3 Jahre [Early childhood: zero to three]. Heidelberg, Springer 2012

25. Flechner S. On aggressiveness and violence in adolescence. Int $\mathbf{J}$ Psychoanal 2005; 86(5):1391-1403.

26. Egloff G. Integrative Psychoanalyse. In: Janus L, Kurth W, Reiss HJ, Egloff G (eds). Verantwortung für unsere Gefühle [Responsibility for our emotions]. Jahrbuch für psychohistorische Forschung 16. Heidelberg, Mattes 2015; 303-331.

27. Sartorius N. Mental health in context. Impact of economic policies on health services. Eur Psychiatry 2016; 33(4):S36.

28. Cierpka M. Faustlos. Ein Curriculum zur Förderung sozialemotionaler Kompetenzen und zur Gewaltprävention für den Kindergarten [Faustlos. A curriculum for pre-school promoting social-emotional competencies and preventing violence] (Coauthored by Schick A, Ott I, Egloff G). Heidelberg, University of Heidelberg 2002 
29. Beland K. Second Step: A Violence Prevention Curriculum. Seattle, Committee for Children 1988.

30. Cierpka M. Faustlos - wie Kinder Konflikte gewaltfrei lösen lernen [Faustlos - how children learn to solve conflicts non-violently]. Freiburg, Herder 2005.

31. Rochford L. Panic in childhood. In: Kilgus MD, Rea WS (eds). Essential Psychopathology Casebook. New York/London, Norton 2014; 425-447.

32. Brede K. Freud als Beobachter. Die Fallstudie „Bruchstück einer Hysterie-Analyse“ [Freud as Observer: The Case Study „Fragment of a Case of Hysteria"]. Psyche - Z Psychoanal 2002; 56(3): 235.

33. Green A. Chiasmus: Hysterie und Grenzfälle [Chiasmus: Hysteria and Borderline]. Psyche - Z Psychoanal 2000; 54(12):1191-1221.

34. Egloff G. Friedrich Nietzsche als Grossvater der Tiefenpsychologie [Friedrich Nietzsche, Grandfather of Depth-Psychology]. Conference Presentation, Dept. Psychosomatische Kooperationsforschung und Familientherapie, Psychosomatische Klinik, Universitätsklinikum Heidelberg, Jan. 8, 2002.

35. Luckhurst R. Traumaculture. New Formations 2003; 50(3):28-48.

36. Schluep N, Hassim J. Prognosis in Context. In: Williams J (ed). Psychopathology - Symptoms, Challenges, and Current Concepts. New York, Nova Science 2016; 1-28.

37. Schick A, Cierpka M. International evaluation studies of Second Step, a primary prevention programme: a review. Emotional and Behavioural Difficulties 2013; 18(3):241-247.

38. Cierpka M, Egloff G, Schick A, Ott I. Pilotprojekt Faustlos Kindergarten. Heidelberg, University of Heidelberg 2001.

39. Cierpka M, Schick A, Egloff G. Evaluation des FaustlosCurriculums für den Kindergarten. Heidelberg, University of Heidelberg 2004.

40. Cierpka M, Schick A. Die Evaluation des Faustlos-Curriculums für den Kindergarten [The evaluation of the Faustlos curriculum for kindergarten]. Prax Kinderpsychol Kinderpsychiatr 2006; 55: 459-474.

41. Schick A, Cierpka M. Faustlos: Evaluation eines Curriculums zur Förderung sozial-emotionaler Kompetenzen und zur Gewaltprävention in der Grundschule [Faustlos: evaluation of a curriculum for social-emotional competencies and preventing violence in elementary school]. Kindheit und Entwicklung 2003; 12:100-110.

42. Schick A, Ott I. Gewaltprävention an Schulen - Ansätze und Ergebnisse [Violence prevention at school - approaches and results]. Prax Kinderpsychol Kinderpsychiatr 2002; 51:766-791.

43. Schick A, Cierpka M. Faustlos: Aufbau und Evaluation eines Curriculums zur Förderung sozialer und emotionaler Kompetenzen in der Grundschule [Faustlos: structure and evaluation of a curriculum for social and emotional competencies in elementary school]. In: Dörr M, Göppel R (eds). Bildung der Gefühle. Innovation? Illusion? Intrusion? [Education of Emotions]. Giessen, Psychosozial 2003; 146-162.

44. Schick A, Cierpka M. Faustlos: Ein Gewaltpräventions-Curriculum für Grundschulen und Kindergärten [Faustlos: a curriculum for elementary school and kindergarten preventing violence]. In: Melzer W, Schwind HD (eds). Gewaltprävention in der Schule [Violence Prevention at School]. Baden-Baden, Nomos 2004; 54-66.

45. Schick A, Cierpka M. Förderung sozial-emotionaler Kompetenzen mit Faustlos: Konzeption und Evaluation der Faustlos-Curricula. [Promoting social-emotional competencies through Faustlos: concept and evaluation of Faustlos curricula]. Bildung und Erziehung 2010; 63(3):277-292.

46. Egloff G, Djordjevic D, Cierpka M. Socio-emotional learning through Faustlos in Germany. In: Brekhman G, Sovilj M, Rakovic D (eds). Proceedings of the $1^{\text {st }}$ Intl. Congress on Psychic Trauma PTPPPA. Belgrade, Life Activities Advancement Center/Institute for Experimental Phonetics and Speech Pathology 2015; 340-345.

47. Seel NM, Hanke U. Erziehungswissenschaft [Textbook Educational Science]. Heidelberg, Springer 2015.

48. Government of the Republic of Serbia. 'School Without Violence' Project. http://www.srbija.gov.rs/razno/pretrazivanje.php?q=school +without+violence

49. United Nations, Serbia. A five-year programme of cooperation with the Government of the Republic of Serbia, 'School Without Violence' Project. https://www.unicef.org/serbia/activities_936. html

50. United Nations, Serbia. 'School Without Violence' 5 Years Later Lessons Learned. https://www.unicef.org/serbia/support_4696.html. 